\title{
EFEKTIVITAS FORMAT PENDOKUMENTASIAN KEPERAWATAN MODEL PROBLEM ORIENTED RECORD (POR) TERHADAP KEMUDAHAN PENGGUNAANNYA OLEH PERAWAT DI RAWAT JALAN RSUD PETALA BUMI PEKANBARU TAHUN 2013
}

\author{
Hirzal $^{1}$., Ardenny ${ }^{2}$, Delvira $^{3}$ \\ zal_hir@yahoo.com
}

\begin{abstract}
ABSTRAK
Pendokumentasian keperawatan merupakan kegiatan yang harus dilaksanakan oleh perawat. Fenomena yang ditemukan di RSUD Petala Bumi Pekanbaru adalah belum tersedianya format pendokumentasian keperawatan khususnya di rawat jalan yang baku dan sesuai standar. Penelitian ini bertujuan untuk mengetahui efektivitas format pendokumentasian keperawatan model problem oriented record (POR) terhadap kemudahan penggunaannya oleh perawat di rawat jalan RSUD Petala Bumi Pekanbaru. Penelitian ini menggunakan metode quasi experiment dengan post test one only group design. Sampel penelitian adalah seluruh perawat pelaksana di sembilan ruangan di rawat jalan RSUD Petala Bumi Pekanbaru berjumlah 35 perawat. Instrumen yang digunakan adalah karakteristik responden (jenis kelamin, umur, pendidikan, masa kerja dan pelatihan yang diikuti) dan intrumen format pendokumentasian keperawatan model problem oriented record (POR) yang dirancang peneliti dengan metode check list yang dilakukan empat kali pengukuran terhadap lama pengisian format, kelengkapan pengisian, kebenaran pengisian format dan persepsi perawat tentang kemudahan penggunaannya. Hasil penelitian menunjukkan terdapat perbedaan yang signifikan dari lama pengisian format, kelengkapan pengisian, kebenaran pengisisan dan persepsi perawat antar pos test tentang kemudahan penggunaan format model POR ( $\mathrm{p}$ value $=0,000 ; \alpha: 0,05$ ). Direkomendasikan bagi institusi pelayanan agar berupaya meningkatkan dan evaluasi sistem pendokumentasian keperawatan dengan format model POR yang sudah ada. Bagi peneliti lain disarankan untuk melakukan penelitian kualitatif terhadap penggunaan format pendokumentasian model POR dari aspek individu, kelompok atau organisasi metode cheklis di integrasikan SIMKEP.
\end{abstract}

Kata kunci $\quad$ : Dokumentasi keperawatan, Problem Oriented Record, Kemudahan

\section{ABSTRACT}

Documentation of nursing is an activity that must be carried out by nurses. The phenomenon is found in Petala Bumi Hospital Pekanbaru with nonavailabilities format documentation of nursing especially in the outpatient based on standart. This research aims at knowing the format of the documentation of the effectiveness of nursing model of problem oriented record (POR) with respect to the ease of its use by nurses in outpatient Petala Bumi Hospital Pekanbaru. This research uses quasi experiment method with post test one only group design. The research sample is the entire managing nurses in nine rooms of patient Petala Bumi Hospital totaled 35 nurses, minimally educated criteria diploma of nursing, not being willing to leave and the respondent. The instruments used are the characteristics of respondents (gender, age, education, work and training period that followed) and the instruments of the format of the documentation of nursing model of problem oriented record (POR) researchers designed with the method of check list is done four times the measurement of long charging charging format, completeness, correctness of filling of the format and the perception of the nurse about the ease of its use. 
Results showed that there were Repeated ANOVA testing with a significant increase of the length of the charging complate charging, true, entries and nurses perceptions about the ease of the use of the form model POR at each measurement ( $p$ value $=0,000 ; \alpha: 0,05$ ). It was recommended for institutional services to improve the system of evaluation and documentation of nursing with the format model POR. The researcher are advised to do a qualitative research on the use of the format of the documentation of the individual aspects of model POR, group or organization method of cheklist integrated SIMKEP.

Keywords $\quad$ : Nursing Documentation, Form Problem Oriented Record, Accessibility.

\section{Pendahuluan}

Pendokumentasian merupakan kegiatan pencatatan dan pelaporan yang penting dilakukan oleh perawat karena melalui pencatatan dan pelaporan semua kegiatan perawat akan terdokumentasi dengan baik. Pendokumentasian adalah kegiatan menuliskan data kesehatan sehingga bisa dibaca yang merupakan proses keperawatan sebagai dasar dalam memberi asuhan keperawatan. (Huston, 2008; Heartfield 2008). Hal ini didukung oleh Kozier (2005), pendokumentasian merupakan bukti akuntabilitas tindakan keperawatan yang dilakukan perawat dalam pelayanan keperawatannya terhadap pasien. Perawat juga dituntut untuk menerapkan dokumentasi keperawatan sebagai tanggung jawab profesi dan aspek legal. Kelengkapan dokumentasi keperawatan merupakan salah satu indikator mutu asuhan keperawatan yang diberikan.

Peningkatan mutu pelayanan di rumah sakit harus melibatkan semua unsur, termasuk didalamnya adalah unsur manajer melalui fungsi manajemen yang terdiri dari lima fungsi manajemen menurut Fayol (1908, dalam Stoner, Freeman dan Gilbert, 1996) yaitu planning, organizing, leading, coordinating, and controlling. Sedangkan Gullick (2008) mengemukakan konsep planning, organizing, staffing, directing, coordinating, reporting, budgeting atau dikenal dengan akronim POSDCORB (Schlosser, 2009). Fungsi pencatatan dan pelaporan (reporting) merupakan salah satu fungsi yang berhubungan dengan pelaksanaan pendokumentasian.

Fungsi pencatatan dan pelaporan berhubungan erat dengan fungsi koordinasi, dimana dalam organisasi harus ada orang yang bertanggungjawab mencatat dan melaporkan tentang apa yang sedang terjadi (Vsanthakumar \& Waldron, 2010). Hal ini sesuai dengan pendapat Fisbach (2011) yang menyatakan bahwa pelaksanaan dokumentasi asuhan keperawatan dipakai sebagai alat ukur untuk mengetahui dan memantau kualitas pelayanan asuhan keperawatan yang 
diselenggarakan di rumah sakit. Semua kegiatan yang dilakukan oleh perawat baik sebagai pelaksana ataupun sebagai manajer harus dicatat dan dilaporkan sebagai laporan kinerja yang bisa dijadikan sebagai bahan evaluasi untuk pengambilan keputusan.

Pengaruh pendokumentasi keperawatan bagi Rumah Sakit menurut Murphy (2009), menyatakan bahwa dapat memberikan informasi tentang kegiatan pelayanan, media komunikasi bagi tenaga kesehatan lain, bisa digunakan sebagai program penjaminan mutu, dasar pemberian jasa pelayanan dan yang paling penting adalah sebagai alat pertahanan diri yang akan dipergunakan bila terjadi tututan atas kesalahan medis yang timbul dalam pemberian asuhan keperawatan. Hal ini didukung pula oleh pernyataan Iyer (2005), menunjukkan adanya pelaksanaan pendokumentasian yang dirumuskan dapat mengatasi permasalahan pasien, menigkatkan kepuasan pasien akan standar dokumentasi keperawatan, meningkatkan outcome pasien, serta proporsi kesembuhan dan lama hari rawat pasien lebih besar yang menerapkan standar pendokumentasian.

Pelaksanaan dokumentasi memegang peranan penting dalam penilaian kinerja perawat di ruang rawat inap maupun rawat jalan. Menurut Iyer dan Camp (2005) mengatakan bahwa dokumentasi asuhan keperawatan merupakan mekanisme yang digunakan untuk mengevaluasi asuhan keperawatan yang telah diberikan kepada pasien, yang telah dilaksanakan oleh perawat pelaksana. Hal ini didukung Perry dan Potter, (2010) dokumentasi sebagai segala sesuatu yang tertulis atau tercetak dapat digunakan sebagai catatan dan bukti bagi individu yang berwenang. Dokumentasi yang baik tidak hanya mencerminkan kualitas perawatan tetapi juga membuktikan pertanggunggugatan setiap perawat dalam memberikan perawatan.

Ciri dokumentasi asuhan keperawatan yang baik menurut Potter dan Perry (2010) berdasarkan atas : pertama; fakta (faktual basis), kedua; akurat (accuracy) ketiga; lengkap (completeness), keempat; ringkas (conciseness), kelima; terorganisir sedangkan keenam dan ketujuh adalah waktu yang tepat (time liness) dan bersifat mudah dibaca (legibility).

Model pemberian asuhan keperawatan perlu disesuaikan dengan kondisi dan kebutuhan pasien yang sampai saat ini terdiri dari enam model yang meliputi: $\quad$ SOR (Source Oriented Record), POR (Problem- Oriented Record), Progress Notes, CBE (Charting By Exception), PIE (Problems Intervention and Evaluation), Focus (Process Oriented 
Sistem), (Marquis \& Huston, 2012; Blais, Hayes, Kozier, \& Erb, 2007; Tomey, 2009). Masing-masing model pemberian asuhan keperawatan mempunyai keuntungan dan kerugiannya.Pendokumentasian keperawatan menggunakan model POR mempunyai keuntungan yang dikemukakan oleh Damayanti (2010), bahwa penggunaan model POR mempunyai metode logis untuk melakukan analisis dan pemecahan masalah, memungkinkan komunikasi yang lebih efektif, terdiri atas pembahasan singkat tentang setiap masalah yang ada dalam daftar masalah dan bagaimana masalah tersebut berakhir, apakah berhasil atau tidak berhasil diselesaikan.

Model Pendokumentasian keperawatan menggunakan model problem oriented record (POR) lebih mudah diterapkan karena model ini memusatkan data tentang klien dan didokumentasikan dan disusun menurut masalah klien. Sistem dokumentasi jenis ini mengintegrasikan semua data mengenai masalah yang dikumpulkan oleh dokter, perawat atau tenaga kesehatan lain yang terlibat dalam pemberian layanan kepada klien.

Sebagian perawat merasakan bahwa dalam melaksanakan pendokumentasian proses keperawatan bukanlah menjadi kewajiban profesi melainkan sebagai suatu beban
(Keliat, dkk, 2009). Pernyataan ini didukung dengan hasil evaluasi dokumentasi asuhan keperawatan pada beberapa rumah sakit umum di Indonesia yang menunjukkan bahwa, kemampuan perawat mendokumentasikan asuhan keperawatan rata-rata kurang dari $60 \%$, sedangkan hasil evaluasi dokumentasi keperawatan pada dua rumah sakit jiwa rata-rata kurang dari $40 \%$ yang memenuhi kriteria (Keliat, dkk., 2009). Pelaksanaan dokumentasi keperawatan selama ini di Indonesia masih belum sesuai dengan standar, sehingga sering muncul masalah dalam pelaksanaan asuhan keperawatan. Masalah itu adalah tidak lengkapnya dokumentasi asuhan keperawatan yang dilakukan baik di rumah sakit maupun pelayanan keperawatan yang lainnya. Menurut Widyantoro (2011), permasalahannya adalah rumitnya sistem pendokumentasian asuhan keperawatan, penggunaan dokumentasi yang masih manual, dan pemahamam perawat yang masih rendah tentang pentingnya dokumentasi.

Hambatan dalam pendokumentasian asuhan keperawatan telah diteliti oleh Gugerty dan Maranda, 2010 di Maryland terhadap 933 orang perawat dengan metoda kuantitatif dan kualitatif. Hasil perhitungan secara kuantitatif didapatkan data bahwa $81 \%$ 
pendokumentasian asuhan keperawatan menyita waktu sehingga berdampak langsung terhadap pelayanan, $36 \%$ menyelesaikan pendokumentasian setelah jam kerja selesai, 63\% kelebihan jam kerja harus dibayar oleh rumah sakit, 55\% perawat melakukan pendokumentasian secara berlebihan, $64 \%$ pendokumentasian dilakukan secara manual.

Selain faktor sistem pendokumentasian asuhan yang manual menurut Champ \& Iyer, 2005, hambatan dalam pendokumentasian lainnya adalah belum diterapkannya keseragaman dalam membuat diagnosis keperawatan, rencana tindakan dan pencapaian hasil yang diharapkan. Dokumentasi proses keperawatan yang lengkap, akurat dan sesuai standar, juga akan menjamin kesinambungan proses keperawatan yang diberikan kepada pasien dan sebaliknya apabila tidak lengkap dan tidak sesuai dengan permasalahan pasien akan membuat dokumentasi menjadi tidak berarti dan menimbulkan ketidaksinambungan proses keperawatan. Rumah Sakit Umum Petala Bumi Pekanbaru adalah Rumah Sakit Umum Daerah tipe C dengan pelayanan empat spesialis besar yaitu Penyakit Dalam, Bedah, Anak, Kandungan dan dilengkapi poliklinik PTRM (Program Terapi Rumatan Metadon) dan TB-DOTS.
Jenis ketenagaan yang di miliki oleh Instalasi Rawat Jalan RSUD Petala Bumi memiliki ragam profesi dan jenis, jumlah tenaga perawat sendiri di instalasi rawat jalan RSPB Pekanbaru sebanyak 35 orang dengan kualifikasi pendidikan S1 Kesehatan Masyarakat sebanyak 2 orang (5,7\%), SPK 5 orang (14,3\%), DIII Keperawatan dan Kebidanan 22 orang (62,9\%), DI Kebidanan 4 orang(11,4\%) dan DIV Kebidanan 2 (5,7\%). Berdasarkan rata-rata jumlah kunjungan rawat jalan dalam satu tahun terakhir ini yaitu 5.031 orang, dengan poliklinik kunjungan yang paling tinggi adalah poliklinik umum yaitu 1.676 orang (Data rekam medis RSUD Petala Bumi, 2010).

Praktek Residensi yang dilakukan peneliti tahun 2013, di Rawat Jalan RSUD Petala Bumi Pekanbaru, didapatkan data bahwa pencatatan dan pelaporan kunjungan pasien rawat jalan tertulis di catatan medis. Hal ini disebabkan oleh kerena rendahnya pengetahuan perawat dalam melaksanakan sistim pendokumentasian sesuai standar pelayanan keperawatan. Beberapa alasan yang didapatkan dari hasil wawancara dengan pihak manejer dan kepala ruangan rawat jalan, bahwa sistim pendokumentasian pasien rawat jalan belum pernah direncanakan untuk direvisi sesuai dengan 
standar pelayanan rumah sakit. Alasan ini diperkuat juga dengan lemahnya kebijakan pimpinan rumah sakit untuk memperbaiki masalah yang terjadi khususnya di pendokumentasian rawat jalan.

Beberapa hal yang menjadi penyebab lain dari lemahnya kebijakan seorang pimpinan adalah adanya pergantian direktur rumah sakit sehingga program yang telah disusun tidak dapat direalisasikan dengan baik. Adanya pergantian direktur Rumah Sakit ini mengakibatkan fungsi manajemen rumah sakit belum berjalan secara optimal. Salah satu fungsi manajemen Rumah sakit yang tidak berjalan secara optimal adalah fungsi pengarahan, dimana seorang manajer seharusnya memiliki kemampuan terhadap masalah yang terjadi terutama di rawat jalan yakni tentang pendokumentasian.

Perlu diketahui juga bahwa pada awal berdirinya rumah sakit pada pertengahan tahun 2008, pencatatan dan pelaporan pendokumentasian pasien dicatat di laporan medis. Hingga saat ini belum ada format dokumentasi yang baku yang disahkan oleh direktur untuk dijadikan suatu pedoman pencatatan dan pelaporan khususnya Rawat Jalan.

Hasil survei tersebut diatas menunjukkan bahwa asuhan keperawatan belum terlaksana sesuai dengan standar.

\section{Tujuan Penelitian}

Tujuan penelitian ini adalah untuk mengetahui efektivitas penggunaan format pendokumentasian menggunakan model Problem Oriented Record (POR) terhadap kemudahan penggunaannya oleh perawat di RSUD Petala Bumi Pekanbaru.

\section{Metode Penelitian}

Penelitian ini adalah penelitian quasi experiment dengan menggunakan desain post test one group design (Sugiyono, 2008; Arikunto, 2009). Pada model ini peneliti ingin mengetahui efektivitas penggunaan format pendokumentasian model POR (Problem Oriented Record) pada perawat setelah adanya rancangan format pendokumentasian. Hal ini dilakukan, karena sebelumnya format pendokumentasian model POR belum tersedia di rawat jalan, penggunaan format pendokumentasian keperawatan POR di observasi sebanyak empat kali post test. 


\section{Hasil Penelitian}

\subsection{Karakteristik Responden}

Karakteristik responden meliputi usia, jenis kelamin, tingkat pendidikan, lama kerja, pelatihan pendokumentasian yang pernah diikuti. Pengolahan data karakteristik perawat pelaksana ini menggunakan statistik deskriptif, dan disesuaikan dengan jenis data yang diperoleh, yaitu data numerik meliputi umur dan lama kerja, data kategorik yang terdiri dari jenis kelamin, tingkat pendidikan dan pelatihan yang pernah diikuti. Uraian hasil analisis secara rinci disajikan sebagai berikut:

5.1.1 Umur dan lama kerja perawat pelaksana

Karakteristik perawat pelaksana berdasarkan umur dan lama kerja merupakan variabel numerik, dilakukan analisis dengan menggunakan central tendency dan disajikan pada tabel 5.1 sebagai berikut:

Tabel 5.1

Rerata Umur dan Lama Kerja Perawat Pelaksana di Rawat Jalan RSUD Petala Bumi Pekanbaru Tahun 2013 (n=35)

\begin{tabular}{|c|c|c|c|}
\hline Variabel & Mean & SD & $\begin{array}{l}\text { Min- } \\
\text { Max }\end{array}$ \\
\hline Umur (tahun) & 31,40 & 4,23 & $25-39$ \\
\hline $\begin{array}{l}\text { Lama } \\
\text { (tahun) }\end{array}$ & 5,94 & 2,33 & $2-12$ \\
\hline
\end{tabular}

Berdasarkan penyajian pada Tabel 5.1 ratarata umur perawat pelaksana di rawat jalan RSUD Petala bumi Pekanbaru adalah umur 31,40 tahun, dengan standar deviasi $\pm 4,23$ tahun, umur termuda 25 tahun dan tertua 39 tahun. Sedangkan rata-rata lama kerja perawat pelaksana adalah 5,94 tahun, dengan standar deviasi $\pm 2,33$ tahun. Lama kerja terendah adalah 2 tahun dan terlama adalah 12 tahun.

5.1.2 Jenis Kelamin, pendidikan dan pelatihan dokumentasi yang diikuti

Karakteristik perawat pelaksana berdasarkan jenis kelamin dan status perkawinan merupakan data kategorik, dianalisis dengan menggunakan proporsi dan disajikan pada tabel 5.2 sebagai berikut:

Tabel 5.2

Distribusi Frekuensi Jenis Kelamin, Tingkat Pendidikan dan Pelatihan Pendokumentasian yang diikuti Di Ruang Rawat Jalan RSUD Petala Bumi Pekanbaru Tahun $2013(\mathrm{n}=35)$

\begin{tabular}{llrr}
\hline No & Karakteristik & f & \% \\
\hline 1. & Jenis kelamin & & \\
& Laki-laki & 5 & 14,3 \\
& Perempuan & 30 & 85,7 \\
2. & Pendidikan & & \\
& DIII Keperawatan & 29 & 82,9 \\
& DIV Kebidanan & 2 & 5,7 \\
& S1 Keperawatan & 4 & 11,4 \\
3. Pelatihan & & \\
& pendokumentasian & & \\
& Belum & 31 & 88,6 \\
& Sudah & 4 & 11,4 \\
\hline
\end{tabular}


Berdasarkan Tabel 5.2 disajikan bahwa perawat pelaksana yang bekerja di ruang rawat jalan RSUD Petala Bumi Pekanbaru umumnya berjenis kelamin laki-laki dengan tingkat pendidikan adalah D III Keperawatan, dan belum pernah mengikuti pelatihan pendokumentasian keperawatan.

Tabel 5.3

Rerata Skor Lama Pengisian Format, Kelengkapan Format, Kebenaran Pengisian Format dan Persepsi Perawat Kemudahan Penggunaan Format Model POR di Rawat jalan RSUD Petala Bumi Pekanbaru Tahun 2013

\begin{tabular}{lrrr}
\hline \multicolumn{1}{l}{ Variabel } & Mean & SD & Min-Mak \\
\hline Lama waktu & & & \\
pengisian & & & \\
format & & & \\
- Post test 1 & 6,77 & 1,46 & $4-10$ \\
- Post test 2 & 5,63 & 1,06 & $4-9$ \\
- Post test 3 & 4,91 & 0,98 & $4-8$ \\
- Post test 4 & 4,49 & 0,61 & $3-6$ \\
- Gabungan & 5,45 & 0,67 & $4,25-7,50$ \\
Kelengkapan & & & \\
Pengisian & & & \\
- Post test 1 & 74,94 & 6,85 & $56-87$ \\
- Post test 2 & 79,11 & 4,92 & $65-89$ \\
- Post test 3 & 82,83 & 4,08 & $70-90$ \\
- Post test 4 & 85,77 & 4,71 & $76-94$ \\
- Gabungan & 80,66 & 4,21 & $67,25-$ \\
& & & 89,75 \\
Kebenaran & & & \\
- Post test 1 & 10,66 & 2,83 & $4-15$ \\
- Post test 2 & 12,60 & 2,23 & $8-15$ \\
- Post test 3 & 13,29 & 2,05 & $8-15$ \\
- Post test 4 & 14,06 & 1,25 & $10-15$ \\
- Gabungan & 12,65 & 1,33 & $9,50-$ \\
& & & 15,00 \\
Persepsi & & & \\
- Post test 1 & 46,63 & 3,14 & $40-53$ \\
- Post test 2 & 48,89 & 2,39 & $45-54$ \\
- Post test 3 & 49,71 & 3,80 & $41-58$ \\
- Post test 4 & 56,17 & 2,65 & $51-60$ \\
- Gabungan & 50,35 & 1,80 & $45,75-$ \\
& & & 54,25 \\
\hline
\end{tabular}

Berdasarkan Tabel 5.3 dapat disajikan bahwa dari lama pengisian format yang dilakukan perawat pelaksana dari post test kesatu sampai post test ke empat, rata-rata lama pengisian yang membutuhkan waktu lama terdapat pada post test kesatu 6,77 menit, dengan standar deviasi $\pm 1,46$ menit, sedangkan lama waktu pengisian yang diperlukan perawat di post test keempat lebih singkat dilakukan dengan rerata 4,49 dengan standar deviasi $\pm 0,61$.

Kelengkapan pengisian format pendokumentasian keperawatan model POR oleh perawat diukur dengan penilaian pada rata-rata format yang digunakan oleh masing-masing responden berdasarkan total dokumen yang dinilai sebanyak 35 buah format model POR.

Hasil observasi peneliti pada post test kesatu, post test kedua, post test ketiga dan post test keempat dijumpai format yang telah diisi oleh perawat pelaksana sebagian besar telah mengacu pada tujuan $(64,3 \%)$ dan $(59,5 \%)$ hasil evaluasi dicatat. Catatan tertulis diformat yang berlaku $(75,7 \%)$, catatan ditulis dengan jelas, ringkas (79,5\%), dokumentasi tidak mencantumkan paraf, tanggal serta jam dilakukan tindakan $(62,2 \%)$, berkas disimpan sesuai ketentuan yang berlaku $(86,9 \%)$ dan terdapat tip-ex atau menghitamkan kesalahan $(67,4 \%)$ serta 
$100 \%$ catatan perawat terdapat terdapat ruang kosong yang tersisa. Rata-rata kelengkapan pengisian format dokumentasi model POR di post test kesatu sebesar $75,54 \%$ dengan standar deviasi $\pm 6,81$, sedangkan rata-rata kelengkapan pengisisan format dokumentasi model POR di post test keempat sebesar $85,37 \%$ dengan standar deviasi $\pm 4,63$.

Kelengkapan pengisian format model POR yang dilakukan perawat di rawat Jalan RSUD Petala Bumi Pekanbaru sudah optimal di post test keempat yakni 94,3\% sudah lengkap dan hanya 5,7\% tidak lengkap.

Sedangkan kebenaran perawat pelaksana dalam pengisian format pendokumentasian keperawatan model POR di setiap post tes hampir merata, rerata kebenaran dalam pengisian format model POR pada post test kesatu 10,66 , standar deviasi $\pm 2,83$ namun kesalahan pengisian format di post test kempat mengalami penurunan dilihat nilai mean 14,06, standar deviasi $\pm 1,25$.

Gambaran persepsi perawat pelaksana yang disajikan tabel 5.3 tentang kemudahan penggunaan format dokumentasi keperawatan dengan skor rata-rata kemudahan posttest 146,63 , standar deviasi $\pm 3,14$, sedangkan skor kemudahan penggunaan format POR di posttest keempat terjadi peningkatan kemudahan penggunaannya dengan skor rata-rata 56,17, standar deviasi $\pm 2,65$. Kron (2009) mengemukakan bahwa perolehan skor $\geq 60 \%$ dikategorikan mudah dan tidak mudah bila perolehan skor $<60 \%$.

5.3 Perbedaan kemudahan penggunaan format Model POR berdasarkan lama pengisian, kelengkapan pengisian, kebenaran menengisi dan persepsi perawat pelaksana Kemudahan penggunaan format model POR dilakukan dengan melihat total skor yang dilakukan empat kali post test, peneliti menggunakan uji Repeated ANOVA Measures, dilanjutkan dengan post-hoc paired wise comparisons karena data diperoleh secara berulang dari subjek yang sama. Untuk mengetahui adanya perbedaan pengukuran yang berulang pada variabel dilakukan observasi berdasarkan lama waktu pengisian format, kelengkapan pengisian format, kebenaran dalam mengisi format dan persepsi perawat pelaksana tentang penggunaan format pada masing-masing post test dengan melihat nilai mean difference.

5.3.1 Perbedaan rerata kemudahan penggunaan format model POR.

Perbandingan rerata kemudahan penggunaan format pendokumentasian keperawatan model POR disajikan pada tabel 5.4 
Tabel 5.4

Analisis Rerata Perbedaan Lama Pengisian, Kelengkapan, Kebenaran dan Persepsi Perawat dalam Pengsisan Format Dokumentasi Keperawatan Model POR Di Rawat Jalan RSUD Petala Bumi Pekanbaru Tahun $2013(n=35)$

\begin{tabular}{lrrrrr}
\hline & \multicolumn{4}{c}{ Mean } & \multirow{2}{*}{ Nilai } \\
\cline { 2 - 5 } \multicolumn{1}{c}{ Variabel } & $\begin{array}{r}\text { Post } \\
\text { test 1 }\end{array}$ & $\begin{array}{r}\text { Post } \\
\text { test 2 }\end{array}$ & $\begin{array}{r}\text { Postte } \\
\text { st 3 }\end{array}$ & $\begin{array}{r}\text { Post } \\
\text { test 4 }\end{array}$ & p \\
\hline $\begin{array}{l}\text { Lama (waktu) } \\
\text { pengisian }\end{array}$ & 6,77 & 5,63 & 4,91 & 4,49 & 0,001 \\
Kelengkapan & 74,94 & 79,11 & 82,83 & 85,77 & 0,001 \\
Kebenaran & 10,66 & 12,60 & 13,29 & 14,06 & 0,001 \\
Persepsi perawat & 46,63 & 48,89 & 49,71 & 56,17 & 0,001 \\
\hline
\end{tabular}

Hasil keseluruhan uji repeated ANOVA kemudahan pengggunaan format pendokumentasian keperawatan model POR yang terdiri dari lama pengisian format, kelengkapan pengisian format, kebenaran pengisian format dan persepsi perawat diuraikan sebagai berikut:

Berdasarkan lama waktu yang diperlukan perawat pelaksana dalam pengisian format model POR Rawat Jalan RSUD Petala bumi Pekanbaru, terlihat nilai rerata post test 1 (6,77 menit), post test 2 (5.62 menit), post test $3(4,91$ menit) dan post test $4(4,48$ menit), terlihat nilai rerata terjadi penurunan lama pengisiannya. Hasil uji statistik didapatkan Nilai p sebesar 0,001 $(<\alpha: 0,05)$, sehingga dapat disimpulkan bahwa terdapat pengukuran yang berbeda dari lama pengisian format pendokumentasian keperawatan model POR oleh perawat.
Analisis Uji repeated ANOVA kelengkapan pengisian format pendokumentasian keperawatan model POR oleh perawat di Rawat Jalan RSUD Petala bumi Pekanbaru terlihat nilai mean perbedaaan post test 1 $(74,94)$, post test $2(79,11)$, post test 3 $(82,83)$ dan post test $4(85,77)$. Hasil uji statistik didapatkan Nilai p sebesar 0,000 $<\alpha: 0,05$, sehingga dapat disimpulkan bahwa terdapat pengukuran yang berbeda dari kelengkapan pengisian format pendokumentasian keperawatan model POR oleh perawat.

Sedangkan kebenaran pengisian format model POR oleh perawat di Rawat Jalan RSUD Petala bumi Pekanbaru menggunakan uji repeated ANOVA, terlihat nilai mean perbedaaan post test 1 (10.66), post test 2 (12.60), post test $3(13.29)$ dan post test 4 (14.06), rerata dari nilai kebenaran pengisian format ini merupakan 15 item total kebenaran pengisian format.

Analisis dari uji repeated ANOVA, persepsi perawat pelaksana tentang kemudahan penggunaan format pendokumentasian keperawatan model POR di Rawat Jalan RSUD Petala bumi Pekanbaru, terlihat mean kemudahan penggunaan post test kesatu 46,63 , terlihat peningkatan yang signifikan di post test keempat mean 56,17. Nilai ini adalah $60 \%$ dari total skor jawaban perawat 
tentang kemudahan penggunaan format model POR. Hasil uji statistik didapatkan Nilai $\mathrm{p}$ sebesar $0,001<\alpha: 0,05$, sehingga dapat disimpulkan bahwa terdapat pengukuran yang berbeda dari masingmasing post test persepsi perawat tentang kemudahan penggunaan format pendokumentasian keperawatan model POR.

5.3.2 Perbedaan kemudahan penggunaan format model POR menggunakan Uji PostHoc Paired Wise Comparisons.

Analisis lebih lanjut perbandingan penggunaan format dokumentasi keperawatan model POR oleh perawat disajikan menggunakan pengujian post-hoc paired wise comparisons, berdasarkan pengukuran lama pengisian dan kelengkapan disajikan pada diagram 5.1 berikut ini:

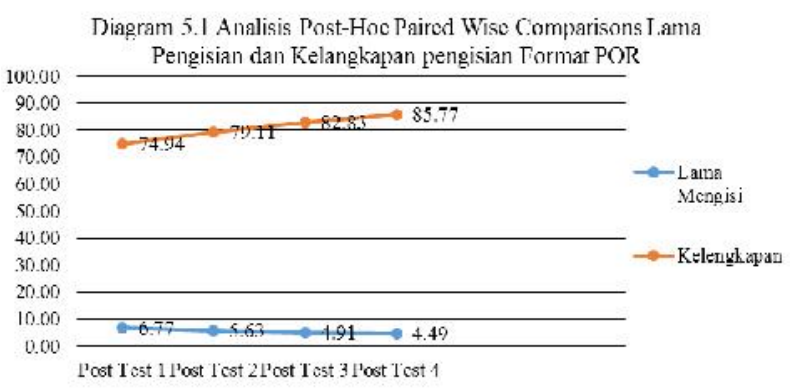

Berdasarkan Diagram 5.1 dapat disajikan bahwa perbandingan pengukuran lama waktu dalam pengisian format dokumentasi keperawatan model POR yang dilakukan perawat pelaksana didapatkan nilai mean difference post test kesatu sampai post test ke empat untuk setiap perbandingan menggunakan uji pairwise comparisons didapatkan hasil yang signifikan Nilai $p$ 0,$001 ; \alpha: 0.05$. Berdasarkan hal tersebut dapat disimpulkan bahwa terdapat perbedaan lama waktu pengisian format pendokumentasian keperawatan model POR pada semua post test yang dilakukan.

Demikian pula analisis menggunakan uji post-hoc paired wise comparisons didapatkan mean difference kelengkapan pengisian format dokumentasi keperawatan dari post test kesatu hingga post test keempat menunjukkan terjadi peningkatan kelengkapan pengisian format dokumentasi keperawatan oleh perawat dengan hasil yang signifikan dengan nilai $\mathrm{p} 0,001$.

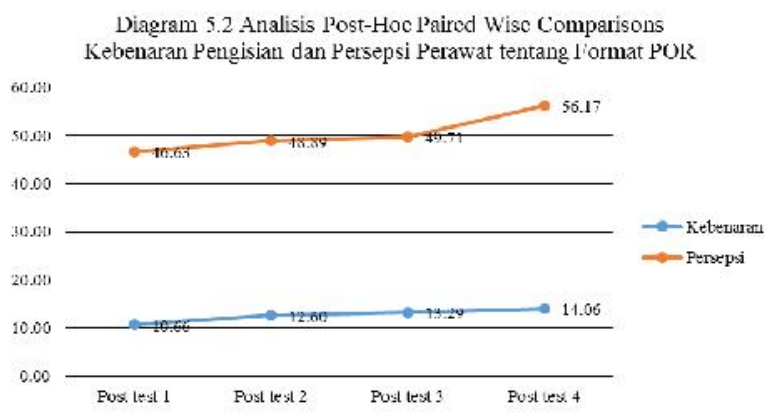

Hasil uji repeated ANOVA yang dilanjutkan dengan analisis post-hoc paired wise comparisons didapatkan mean difference kebenaran pengisian format dokumentasi keperawatan di post test ke satu dan keempat perawat pelaksana banyak mengisi salah namun terjadi penurunan kesalahan dalam pengisian di post test ketiga dan keempat, secara substansi terjadi 
peningkatan yang cukup signifikan rerata kebenaran pengisian format model POR. Hal ini didukung oleh hasil uji statistik yang menunjukkan ada perbedaan rata-rata nilai kebenaran perawat dalam pelaksanaan dokumentasi asuhan keperawatan di Rawat Jalan RSUD Petala Bumi Pekanbaru didapatkan Nilai p 0,$001 ;<\alpha: 0,05$.

Hasil uji repeated ANOVA dilanjutkan dengan post-hoc paired wise comparisons didapatkan mean difference persepsi perawat tentang kemudahan penggunaan format dokumentasi keperawatan pada post test kesatu dan keempat, artinya perawat pelaksana mempersepsikan bahwa format tidak mudah digunakan, namun dipost test ketiga dan keempat perawat mempersepsikan bahwa format model POR yang adalah mudah digunakan, secara substansi terjadinya peningkatan yang cukup signifikan rata-rata perbedaan persepsi perawat tentang kemudahan format model POR. Hal ini didukung oleh hasil uji statistik yang menunjukkan ada perbedaan rata-rata nilai persepsi perawat dalam pelaksanaan dokumentasi asuhan keperawatan di Rawat Jalan RSUD Petala Bumi Pekanbaru didapatkan Nilai $p$ 0,001; $\alpha$ : 0,05 .

\section{Pembahasan}

6.1. Interpretasi dan Diskusi Hasil Penelitian 6.1.1 Efektivitas penggunaan format dokumentasi model POR terhadap lama pengisian.

Lama penggunaan format pendokumentasian keperawatan model POR dilihat dari efesiensi waktu pengisian oleh perawat pelaksana di rawat jalan RSUD Petala Bumi Pekanbaru, peneliti melakukan uji statistik Repeated ANOVA dengan tingkat signifikan $\mathrm{p}<0,05$. Berdasarkan uji statistik Repeated ANOVA diketahui bahwa hasil signifikansi post test kesatu, post test kedua, post test ketiga dan post test keempat, ada perbedaan/signifikan dengan lama waktu yang pengisian format yang artinya pada post test kesatu sampai post test keempat menunjukkan nilai signifikan $\mathrm{p}<0.05$, maka Ho di tolak dan H1 diterima artinya ada penurunan lama waktu pengisian format pendokumentasian keperawatan model POR oleh perawat pelaksana di rawat jalan RSUD Petala Bumi Pekanbaru.

Lama pengisian format pendokumentasian model POR oleh perawat lebih efesien penggunaannya dilihat dari post test kesatu dengan rata-rata waktu yang diperlukan untuk pengisian format selama 4-10 menit namun waktu yang lebih singkat dan efesien di post test keempat yaitu 3-6 menit. Hal ini 
sesuai dengan pengertian efesiensi menurut Kamus Besar Bahasa Indonesia (KBBI) 2010 yaitu, "tepat atau sesuai untuk menghasilkan (mendapatkan) sesuatu dengan tidak membuang-buang waktu, tenaga dan biaya, dengan arti kata mampu menjalankan tugas dengan tepat, cepat, cermat berdaya guna dan tepat guna".

Penelitian ini sejalan dengan hasil penelitian Ehrenberg, dkk (2012) kemudahan pendokumentasian keperawatan (output) yang berupa informasi yang dihasilkan oleh pendokumentasian yang digunakan. Pengguna format dokumentasi akan merasa mudah apabila kemudahan penggunaan yang dihasilkan memenuhi kriteria akurat, tepat waktu, relevan, mudah dipahami dan benar.

Kemudahan penggunaan format dokumentasi keperawatan menurut Nahm (2010), sangat dipengaruhi atau ditentukan oleh tiga hal pokok atau pilar informasi yaitu relevan (relevancy), tepat waktu (timelinness) dan akurat (accuracy). Sejalan pendapat dari Moen (2013) yang mengatakan bahwa informasi yang dihasilkan dari format dokumentasi keperawatan model POR lebih menjamin ketelitiannya/accuracy dan dapat diperoleh dalam waktu yang cepat serta tepat.
Hasil penelitian Heartfield (2008), tentang pengaruh penerapan format pendokumentasian secara manual di rawat inap yang menemukan aspek kemudahan penggunaanya mengalami peningkatan dari sebelum pelatihan dan penerapannya. Aspek lain yang diteliti yaitu tepat waktu, relevansi, kecepatan, tidak duplikasi, mudah dan manfaat menunjukkan mengalami peningkatan atau ada perbedaan dengan $\mathrm{p}<$ 0,05 .

Hal ini dikarenakan penerapan format dokumentasi keperawatan model POR meminimalkan terjadinya kesalahan dalam penulisan maupun dalam pembacaan oleh perawat. Dari hasil pengamatan yang dilakukan oleh peneliti ditemukan adanya keinginan dan keseriusan perawat dalam penerapan format dokumentasi keperawatan model POR oleh perawat di Ruang rawat jalan RSUD Petala Bumi Pekanbaru apabila waktu pengisiannya lebih efesien.

Format pendokumentasian model POR menurut persepsi perawat cukup sistematis cukup efektiv, dan cukup mudah untuk dikerjakan sehingga dapat disimpulkan bahwa format model POR di rawat jalan RSUD Petala Bumi Pekanbaru setuju untuk digunakan. 
6.1.2 Efektivitas penggunaan format POR terhadap kelengkapan pengisian oleh perawat pelaksana.

Kelengkapan pengisian format pendokumentasian keperawatan model POR oleh perawat diukur dengan penilaian pada rata-rata nilai format yang dibuat oleh masing-masing responden berdasarkan total dokumen yang dinilai sebanyak 35 buah format.

Berdasarkan hasil uji statistik Repeated ANOVA diketahui bahwa peningkatan skor kelengkapan pengisian format pendokumentasian keperawatan Model POR pada post kesatu hanya 74,94 , namun terjadi peningkatan di post test keempat yaitu 85,77. Hasil pengukuran lebih lanjut dilihat dari post-hoc paired wise comparisons diketahui hampir semua tahap kelengakapan pengisian format mengalami peningkatan yang bermakna dilihat dari post test ketiga dan post test keempat perawat sudah optimal melakukan pengisian format sehingga nilai mean difference menjadi 2.94 dari total $60 \%$ kelengkapan pengisian format model POR yang dilakukan oleh perawat.

Dari hasil observasi peneliti terhadap format yang diisi perawat pelaksana , ketidaklengkapan pengisian didapatkan adalah penulisan tidak berisi hasil pemeriksaan fisik dan penunjang medis, hal ini dikarenakan pada instalasi rawat jalan ada beberapa pasien yang datang ke rumah sakit untuk merencanakan operasi atau juga melanjutkan pengobatan seperti kemoterapi sehingga tidak diperlukan adanya pemeriksaan fisik maupun pemeriksaan penunjang.

Hal ini didukung oleh penelitian yang dilakukan oleh Sastradijaya (2010), yang menyatakan bahwa kinerja perawat dalam melakukan pendokumentasian didapatkan jumlah data yang hampir sama pula antara perawat yang membuat dokumentasi lengkap dan benar dengan perawat yang membuat dokumentasi kurang lengkap dan kurang benar.

Hasil penelitian ini menunjukkan bahwa kelengkapan yang dipersepsikan oleh perawat maupun berdasarkan hasil observasi merupakan proses yang dinamis dan senantiasa berfluktuasi dengan cepat. Hasil penelitian lain mengungkapkan yang dibuktikan oleh Trisnawati (2008), yang meneliti kinerja perawat berdasarkan kelengkapan dokumentasi asuhan keperawatan menunjukkan bahwa perawat sering tidak mengisi: pertama, format dokumentasi evaluasi $(81,7 \%)$, kedua format dokumentasi intervensi $(59,8 \%)$, dan ketiga format rencana keperawatan $(51,2 \%)$. 
Analisa lebih lanjut, menurut peneliti terjadi variasi peningkatan kelengkapan penerapan format dokumentasi keperawatan dimasingmasing post test dilakukan sangat dipengaruhi oleh input, proses dan output. Faktor input meliputi faktor teknis, faktor perilaku dan faktor organisasi dalam keperawatan. Proses yang dianalisis adalah dalam hal pengumpulan data, analisa data yang dilakukan oleh perawat, kualitas pengecekan data dan umpan balik yang dilakukan oleh perawat di rawat jalan. Dilihat dari aspek kelengkapan format POR yang diisi oleh perawat sudah efektif dan mudahan penggunaanya.

6.1.3 Efektivitas penggunaan format POR terhadap kebenaran pengisian format oleh perawat pelaksana.

Hasil penelitian menunjukkan bahwa dari uji repeated ANOVA kebenaran pengisian format pendokumentasian keperawatan model POR oleh perawat di Rawat Jalan RSUD Petala bumi Pekanbaru terjadi peningkatan dilihat nilai mean post test 1 $(10,66)$ dan post test $4(14,06)$, dari nilai total 15 kebenaran pengisian format. Hasil uji statistik didapatkan nilai $\mathrm{p}$ sebesar $0.000<\alpha$ : 0.05 .

Dalam penelitian ini peneliti menemukan 13 item kesalahan dari 21 item skor observasi penilaian kebenaran pengisian format model
POR yang diisi oleh perawat pelaksana. Hasi pencatatan di format POR oleh perawat di post test kesatu dijumpai isian ceklist dicoret kemudian diperbaiki dan tidak diparaf perawat. Hal ini menunjukkan bahwa perbaikan kesalahan pencatatan yang dilakukan oleh perawat belum mengikuti aturan yang ada atau sesuai dengan teori. Dari hasil observasi terhadap 35 format yang diisi perawat pelaksana karena kesalahan ditipe-ex sebanyak 10 item, melalui kegiatan pendampingan yang dilakukan peneliti selama penelitian mengalami penurunan kesalahan dalam pengisian format POR di post tes keempat.

Dokumentasi keperawatan dikatakan berkualitas baik bila akurat, lengkap dan benar sesuai standar (Champ \& Iyer, 2005; Potter \& Perry, 2009). Akibat dari pendokumentasian yang tidak benar dalam pengisian format dokumentasi keperawatan dapat menyebabkan kesinambungan asuhan keperawatan terputus dan peningkatan mutu pelayanan keperawatan menjadi terhambat. Untuk itu sangat diperlukan kemampuan perawat dalam logis dan analitik dengan menggunakan langkah-langkah proses keperawatan sebagai kerangka kerja yang ilmiah sehingga mampu mendokumentasikan secara benar dan mengatasi setiap permasalahan yang muncul pada pasien. 


\subsubsection{Efektivitas penggunaan format POR} terhadap persepsi perawat pelaksana.

Hasil penelitian menunjukkan bahwa dari uji repeated ANOVA persepsi perawat tentang kemudahan format pendokumentasian keperawatan model POR oleh perawat di rawat jalan RSUD Petala bumi Pekanbaru terjadi peningkatan dilihat dari post test kesatu hingga post test keempat.

Hasil pengukuran lebih lanjut dilihat dari post-hoc paired wise comparisons diketahui hampir semua persepsi perawat tentang kemudahan penggunaan format model POR mengalami peningkatan yang bermakna dilihat dari post test kedua dan post test ketiga persepsi perawat tentang kemudahan pengisian format sehingga nilai mean difference menjadi 0,82 dari total $60 \%$ jawaban responden tentang kemudahan pengisian format model POR yang dilakukan oleh perawat.

Menurut Allan dan Englebright (2010), dengan sistem pendokumentasian dengan manual, efektifitas pendokumentasian bisa dipertahankan dimana perawat mampu melakukan analisa terhadap asuhan keperawatan yang telah diberikan karena mereka dengan mudah bisa menentukan status diagnosa atau masalah keperawatan pada pasien dengan cara ceklist. Selain itu, dengan menggunakan manual seluruh asuhan keperawatan bisa tersimpan dengan baik, maka perawat bisa melakukan pengukuran terhadap intervensi keperawatan yang telah mereka berikan.

Pengertian persepsi adalah akal manusia yang sadar meliputi proses fisik, fisiologis dan psikologis yang mengolah bermacam macam input sebagai penggambaran lingkungan. Hal ini dikemukan oleh Koentjaraningrat (2007) bahwa Persepsi merupakan perlakuan melibatkan penafsiran melalui proses pemikiran tentang apa yang dilihat, didengar, dialami, atau dibaca sehingga persepsi mempengaruhi tingkah laku, percakapan, serta perasaan seseorang. Sebagian besar perawat di unit rawat jalan RSUD Petala Bumi Pekanbaru setuju bahwa format dokumentasi keperawatan model POR merupakan format yang mudah dikerjakan dan sesuai dengan kebutuhan dan standar yang telah ditetapkan. Perawat pelaksana juga mempersepsikan bahwa kegiatan pengisian format merupakan tugas dan tanggungjawab pekerjaan berkontribusi dalam melaksanakan pendokumentasian asuhan keperawatan. Perawat sudah memiliki kesadaran akan tugas dan tanggungjawabnya sehingga perawat berusaha semaksimal mungkin untuk meningkatkan pengetahuannya dalam 
pendokumentasian asuhan keperawatan menggunakan model POR.

Hal tersebut sesuai dengan pernyataan tentang beberapa kelebihan penggunaan format dokumentasi secara manual yang disampaikan oleh Ehnfors., (2009, dalam Potter \& Perry, 2009) adalah peningkatan waktu bersama klien, akses informasi menjadi lebih baik, peningkatan kualitas dokumentasi dan peningkatan kepuasan kerja perawat. Pendokumentasian asuhan keperawatan sangat penting dilakukan, hal ini perlu mengingat catatan tersebut dapat digunakan sebagai alat untuk mengevaluasi perawat dalam melakukan tindakannya terhadap pasien. Apabila di kemudian hari ada kasus hukum yang berkaitan dengan pasien tertentu maka catatan asuhan keperawatan dapat dijadikan bukti sah terhadap tindakan yang dilakukan oleh perawat.

\subsection{Keterbatasan penelitian}

Pelaksanaan penelitian ini praktis tidak mengalami kendala yang berarti. Direktur Rumah Sakit dan jajarannya sangat mendukung terhadap kegiatan ini. Namun begitu, ada keterbatasan yang mengindikasikan untuk merekomendasikan penelitian lanjutan. Keterbatasan dalam penelitian ini adalah:
6.2.1 Proses penyempurnaan dari format dokumentasi keperawatan model POR yang berulang-ulang yang dilakukan oleh peneliti, sehingga memerlukan proses waktu yang lama untuk memahaminya.

\subsection{Implikasi Keperawatan}

\subsubsection{Pelayanan Keperawatan}

Hasil penelitian menunjukkan pentingnya adanya format dokumentasi keperawatan dan memiliki implikasi yang bermanfaat bagi pihak manajemen rumah sakit untuk dapat meningkatkan pelayanan keperawatan, khususnya dalam penggunaan format dokumentasi keperawatan model POR. Penggunaan format dokumentasi model POR ini perlu mendapatkan perhatian akan peran dan fungsinya untuk membantu menyelesaikan tugas keperawatan agar lebih cepat, akurat dan efektif dengan meminimalkan dampak negatifnya. Format dokumentasi keperawatan model POR yang diterapkan di rawat jalan RSUD Petala Bumi Pekanbaru adalah suatu terobosan yang sebelumnya tidak ada format yang baku dan standar yang dibuat oleh rumah sakit.

\subsubsection{Penelitian keperawatan}

Penelitian ini menggambarkan efektivitas penggunaan format dokumentasi keperawatan model POR. Hasil penelitian ini dapat dijadikan dasar bagi penelitian 
berikutnya yang menggali faktor-faktor lain terkait dengan peningkatan pendokumentasian keperawatan secara khusus dan peningkatan pelayanan keperawatan pada umumnya serta analisis kesiapan sumber daya manusia dalam penerapan format pendokumentasian keperawatan.

\section{Kesimpulan}

7.1.1 Karakteristik perawat pelaksana di Rawat Jalan RSUD Petala Bumi Pekanbaru rata-rata berusia produktif dan lama kerja rata-rata enam tahun. Perawat dengan jenis kelamin perempuan lebih banyak dibandingkan jumlah perawat laki-laki, perawat yang mengikuti pelatihan pendokumentasian sedikit dibandingkan dengan perawat yang belum mengikuti pelatihan.

7.1.2 Terdapat perbedaan lama pengisian format, kelengkapan pengisian format, kebenaran pengisian dan persepsi perawat antar post test terhadap penggunaan format model POR oleh perawat pelaksana secara statistik terdapat perbedaan bermakna didapatkan nilai $\mathrm{p} 0,001 ;<\alpha: 0.05$.

\section{Saran}

Berdasarkan hasil penelitian ini, maka peneliti menyarankan kepada;

\subsubsection{Untuk manajemen Rumah Sakit}

7.2.1.1 Perlunya dibuat suatu kebijakan tentang sistem pendokumentasian keperawatan dilengkapi sarana dan prasarana untuk meningkatkan pelayanan keperawatan.

7.2.1.2 Penting adanya upaya menyelenggarakan pelatihan asuhan keperawatan, agar kemampuan perawat pelaksana dalam memberikan pelayanan keperawatan dapat meningkat dan sesuai dengan standar yang ditetapkan. Pelatihan dapat diselenggarakan dengan mengundang konsultan keperawatan yang berpengalaman untuk memberikan materi pelatihan.

7.2.1.3 Perlu adanya tindak lanjut dan pengawasan dari Pelayanan Medik dan Keperawatan RSUD Petala Bumi Pekanbaru untuk pelaksanaan sistem pendokumentasian keperawatan di rawat jalan dengan format model POR yang ada.

7.2.2 Untuk bidang keperawatan

7.2.2.1 Penerapan sistem pendokumentasian keperawatan perlu monitoring, evaluasi lebih lanjut dan diterapkan pada semua rawat jalan di RSUD Petala Bumi Pekanbaru.

7.2.2.2 Membuat SOP tentang penerapan format pendokumentasian pada perawat 
rawat jalan agar dapat memberikan bimbingan bagi teman sejawat.

\subsubsection{Untuk kepala Ruangan}

7.2.3.1 Kepala Ruang sebagai penanggung jawab pelayanan keperawatan di ruangan harus selalu memonitor kinerja bawahannya dalam pelaksanaan dokumentasi asuhan keperawatan supaya lebih optimal.

7.2.3.2 Kepala ruangan harus selalu memberikan motivasi, dorongan, dan mengingatkan kepada perawat ruangan untuk selalu mendokumentasikan segala yang telah dilakukan terkait dengan asuhan keperawatan kepada pasien.

7.2.3.3 Perlu dilakukan pengukuran kualitas pendokumentasian keperawatan dan kinerja perawat pelaksana secara rutin minimal setiap enam bulan sekali.

\subsubsection{Untuk peneliti selanjutnya}

Penelitian ini hendaknya dilanjutkan oleh peneliti lain yang berminat dengan model pendokumentasian keperawatan problem oriented record (POR) area penelitian yang lebih luas, seperti:

\subsubsection{Penerapan sistem pendokumentasian} keperawatan yang terintegrasi dengan sistem informasi manajemen rumah sakit/SIMRS.

\subsubsection{Melaksanakan penelitian lanjutan} tentang faktor yang berhubungan dengan kualitas dokumentasi proses keperawatan baik dari aspek individu, kelompok atau organisasi dengan metode pengumpulan data tentang kemudahan penggunaan format dengan lembar observasi/pengamatan, dan wawancara agar mendapatkan hasil pengukuran yang lebih akurat.

\section{Daftar Pustaka}

Allan,J \& Engllebright,J. (2010). PatientCentered Documentation: An Effective and Efficient Use of Clinical Manual Information System. Journal of Nursing Administration 30, (2) 90-95

Arikunto. (2009). Manajemen Penelitian. Rineka Cipta. Jakarta

Burdayat. (2009). Hubungan budaya organisasi dengan kinerja perawat pelaksana dalam pendokumentasian keperawatan di RSUD. Sumedang. Tesis Fakultas Ilmu Keperawatan Universitas Indonesia (FIKUI).

Carpenito. L.J. (1997). Nursing diagnosis: Application to clinical practice 7 th Ed.Philadelphia: J.B Lippincott company.

Doengus. ME. (2008). Nursing care plan: guidelines for planning and documentation patient care (3rd ed) F. A. Davis.

Damayanti, E., (2010). Karakteristik perawat, tingkat pemahaman terhadap proses keperawatan, dan dokumentasi penerapan proses keperawatan di instalasi rawat inap rumah sakit umum Tangerang. Thesis Mahasiswa Magister Kesehatan. Jakarta, Penerbit Pusaka: Universitas Indonesia.

Ehnfors \& Smedby (2009). Effects of introducing a nursing documentation model on content and comprehensiveness of nursing records. ACTA Universitatis 
Upsaliensis, Uppsala. Vol. 29:315-322.

Ehrenberg, A. and M. Ehnfors, (2012). Patient problems, needs, and nursing diagnoses in Swedish nursing home records. Nursing Diagnosis, Vol. 10(2): p. 65-76.

Fajri \& Ratu Aprilia Senja (2010), Kamus lengkap bahasa Indonesia. Jakarta: Difa Publisher

Fishbach. F.T. (2011). Documenting care: communication, the nursing process and documentation standards. Philadelpia, F.A. Davis Company

Gillies. DA.(1994). Nursing Management. A system approach (3rd ed). Philadelpia. WB. Saunders.

Gugerty, B. Maranda,M.J., Beachley,M., \& Navaro, V.B., et al (2010), Challenges and opportuniies in documantation of the nursing care patients, A Report of The Maryland Nursing Workforce Commision, Baltimore Documentation Work Group Retrieved from http://www.mbon.org/commission 2/documentation challenges.pdf

Heartfield, M. (2008) Nursing documentation and nursing practice: a discourse analysis. Journal of Advanced Nursing. Vol. 34(2):15-20.

Hidayat.A.A. (2008). Pengantar dokumnetasi proses keperawatan. Jakarta. EGC

Huber, D. L. (2006). Leadership and nursing care management. Philadelpia. Saunders Elsevier

Iyer, P.W., \& Camp, N.H. (2005). Nursing documentation: a nursing process approach (3rd ed.). St. Louis, MO: Mosby, Inc.

Iyer, Patricia W., \& Camp, Nancy H.(2005). Dokumentasi keperawatan: suatu pendekatan proses keperawatan. Edisi III. Penerbit EGC. Jakarta

Keliat, B.A, dkk, (2009). Proses Keperawatan Kesehatan Jiwa, Edisi 2 Jakarta EGC.

Kozier, B. \& Erb, G., Berman, A. (2005). Fundamental of nursing: concepts process and practice. California: Upper Saddle River

Kron. Gray.dkk. (2009). Evaluation of implementation of nursing diagnosis, intervention, and outcome. International Journal of nursing terminologies and classification. Vol 20 iss 1;pg. 9.7 pgs, Philadelphia. Jan-Mar 2013

Lusianah (2009). Hubungan motivasi dan supervisi terhadap kualitas dokumentasi proses keperawatan di Instalasi Rawat Inap Rumah Sakit Marinir Cilandak Jakarta. Tesis Program Pascasarjana Fakultas Ilmu Keperawatan UI.

Marquis, B.L., \& Huston, C.J. (2008). Leadership roles and management functions nursing. Philadelphia: Lippincott.

Marriner \& Tomey, A., (2009). Guide to nursing management. St. Louis: Mosby Year Book Co

Moen, A., S.B. Henry, and J.J. Warren, (2013). Representing nursing judgements in the Problem Oriented Record. Journal of Advanced Nursing, Vol. 30(4): p. $990-997$

Nahm, R. and I. Poston, (2010). Measurements of the effects of an integrated, point-of-care manual system on quality of nursing documentation and patient satisfaction. Documentation in Nursing, 18(5): p. 220-229.

Namara.Mc. (2010). Documentation care: communication the nursing process and documentation 
standart. Philadelphia: F.A Davis Company.

Nursalam.

(2009).

Manajemen

Keperawatan: aplikasi dalam praktik keperawatan profesional. Edisi II. Salemba Medika. Jakarta.

Notoatmojo, S. (2007). Pengembangan sumber daya manusia. Cetakan ketiga. Jakarta: PT Rineka Cipta.

Potter \& Perry. (2010). Fundamental keperawatan. diterjemahkan oleh Ardina Ferderika. Jakarta: Salemba Medika

Rivera, J. C., \& Paris, K. M. (2002). Use of nursing diagnoses and interventions in public health nursing practice. Nursing Diagnosis, Vol. 13(1), p.15-23.

Riani, AL. (2011). Dokumentasi Keperawatan. Yogyakarta: Graha Ilmu.

Robbins, S.P. (2009). Perilaku Organisasi. Edidi Bahasa Indonesia. Edisi 10. Jakarta: PT Indeks Kelompok Gramedia

Sabri. L. S, S.P. (2009). Statistik Kesehatan. Edisi Revisi. Jakarta. PT. Raja Grafindo Persada

Samsudin. S. (2006). Manajemen sumber daya manusia. Bandung. Pustaka Setia.

Schlosser \& Rebecca (2009). Taylor and Gullick: A comparison of two legendary change agent, New York: Springer.

Setiariny.(2008). Faktor-faktor yang berhubungan dengan pelaksanaan dokumentasian pengkajian keperawatan oleh perawat di ruang rawat inap RSUD Karawang.
Tesis Magister Keperawatan FIKUI. Jakarta

Setyowati \& Rita (2010). Suatu alternatif pemecahan masalah dalam pendokumentasian asuhan keperawatan. Telaah penelitian: Optimalisasi pendokumentasian Keperawatan di RS Dharmais Jakarta. Jurnal Keperawatan Indonesia. Vol II Oktober 2012.

Stoner,J.,A.,F.,Freeman,R.,E.,\& Gilbert,D.,R., (1996). Manajemen, Jilid I-Edisi bahasa Indonesia Alih Bahasa Sindoro, Jakarta: PT.Prenhallindo

Sugiyono. (2008). Metode penelitisan kuantitatif kualitatif. Bandung. Alfabeta.

Siagian, SP. (2009). Manajemen sumber daya manusia. Jakarta: PT. Bumi Aksara.

Thorsteinsson. T. (2009). Written nursing process: it is still useful to nursing eduction. Journal advanced nursing. 19. 315-319.

Vsanthakumar \& Waldron. (2010). Sistem informasi manajemen: studi sistem informasi bebasis komputer. Jakarta: Prehallind

Widyantoro, W. (2005). Hubungan penggunaan sistem informasi keperawatan dengan kelengkapan dokumentasi keperawatan di Rumah Sakit Fatmawati Jakarta Selatan. Tesis. Program Pascasarjana FIK UI 